\title{
Biologi Perbungaan Keladi Tikus (Typhonium flageliforme): Seludang Bunga Menghambat Penyerbukan?
}

\author{
Erlin Rachman \\ Bidang Botani Puslit Biologi LIPI \\ Pusat IImu Pengetahuan Cibinong, CSC \\ Jl. Raya Jakarta- Bogor, km 46 \\ Diterima 01-01-2008 \\ Disetujui 02-02-2009
}

\begin{abstract}
A study on the flower biology on keladi tikus ( $T$. flageliforme) was conducted to uncover if its spathe inhibits pollination from external pollen resources and causes very low fruit set. The spathe box closely envelopes the sexually vital properties of its inflorenscence. Observation was carried out on some plant clump grown on some uniform potting. A hole was made with scalpel about $4 \times 5 \mathrm{~mm}$ on a side of the spathe to break its isolation. Some nearer flowers in same clump were left without treatment at all as experimental control. Parameter observed was presence or absence of seeded fruit setting on spadix. The study result showed that almost all treated flower spadix per potting, set seeded fruits significantly higher $(63,69 \pm 37,64)$ than that of controls $(3,57 \pm 9,45)$ so it is a great possibility that spathe can inhibit partially fruit set. Flower structure and its reproductive phenology were also described.
\end{abstract}

Key words: Flowering biology, spathe box, mutilatif treatment, fruiting induction, spadix, Typhonium flagelliforme (Lodd.) Blume

\section{PENDAHULUAN}

Keladi tikus (Typhonium flagelliforme (Lodd) Blume), merupakan salah satu jenis suku Araceae, yang akhir-akhir ini banyak menarik perhatian karena dipercaya dapat bermanfaat sebagai tumbuhan obat anti kanker, meskipun belum jelas keberadaan senyawa aktifnya. Nama lokal keladi tikus, diberikan pada tumbuhan ini mungkin karena suatu prosesus yang menyerupai ekor tikus pada ujung tongkol bunganya. Tanda pengenal jenis tumbuhan ini di lapangan yang paling mudah terlihat adalah prosesus tersebut. Postur individu di luar bunga tampak seperti keladi biasa namun berukuran kecil; tinggi $10-20 \mathrm{~cm}$, menyukai habitat ternaung dan agak lembab. Hsuan Keng (1978) mencantumkannya dalam anak (sub) suku Aroideae karena bunga-bunga uniseksual dan umumnya telanjang, benangsari bebas atau bersatu membentuk synandria, bakal biji anatropus atau lurus dan biji mempunyai endosperm. Meskipun demikian, kemungkinan besar nama 'keladi tikus' baru dikenal oleh kalangan terbatas tepatnya sejak sarinya (juice)

Telp: 08171172140

Email: erlinrahman@yahoo.com disinyalir dapat mengobati penyakit kanker (Teo \& Teo 1999).

Perkembangbiakan tumbuhan ini lebih banyak secara vegetatif, yaitu melalui pertunasan umbi batang yang berada di bawah permukaan tanah. Pengamatan pendahuluan menunjukan bahwa secara alami pembentukan buah dan biji cukup jarang, meskipun pada keadaan yang cocok tumbuhan ini cukup mudah terjadi perbungaaan. Pembudidayaannya melalui pengecambahan biji tampaknya terkendala terutama oleh kelangkaan suplai biji disamping daya kecambah bijinya rendah dan memerlukan waktu lama.

Pembudidayaan dan konservasi tumbuhan ini perlu penelitian dan pengembangan aspek pembiakan generatifnya terutama tentang pembungaan dan pembuahan. Pengamatan pendahuluan juga menunjukkan bahwa tanaman ini membutuhkan waktu penyesuaian (adaptasi) yang cukup panjang untuk dapat berbuah; meskipun sudah cukup umur (ditandai dengan adanya bunga yang banyak) dan subur namun buah muncul selang 6-12 bulan kemudian. Pembentukan buah serta biji secara alami pun jarang terjadi. Tetapi yang menarik pada prapengamatan selintas di habitat aslinya adalah bahwa pada salah satu sisi kotak seludang kadang-kadang terlihat ada 
satu lubang kecil sekitar $5 \times 5 \mathrm{~mm}$, tampak seperti bekas aktifitas serangga, dan setelah diikuti perkembangannya ternyata dari tongkol bunga yang demikian hampir selalu terbentuk buah/biji di kemudian hari, sehingga menjadi salah satu hal yang inspiratif untuk penelitian ini.

Penelitian ini dimaksudkan untuk mempelajari lebih jauh mengenai biologi bunga dan mencari cara penginduksian terbentuknya buah/biji untuk peningkatan produksi buah dan biji. Penginduksian pembentukan buah dan biji dilakukan dengan memberi perlakuan mutilatif yaitu dengan cara melubangi kotak seludang yang membungkusi semua properti yang secara seksual adalah vital pada tongkol bunga. Perlakuan tersebut mengacu ke percobaan induksi pembentukan buah via perlakuan mutilatif, dengan memangkas tabung korola, pernah berhasil dilakukan terhadap bunga Alamanda cathatica L. (Sreekala \& Sreedevi 2001).

\section{BAHAN DAN METODE}

Bahan tumbuhan yang dipakai dalam penelitian ini adalah semai berupa rumpun kecil tinggi sekitar 5 $10 \mathrm{~cm}$ dengan jumlah daun 2 helai, dikoleksi dari Kotamadya Pekalongan, Jawa Tengah. Semai ditanam dalam polibag yang berisi tanah,pasir , kompos dengan proporsi yang sama dengan penyiraman yang cukup setiap hari. Tanaman mulai berbunga setelah sekitar 2 bulan ditanam. Pengamatan biologi bunga dilakukan setiap hari setelah bunga yang bersangkutan muncul dengan mencatat morfologi dan perubahan-perubahan yang terjadi terutama pada kuncup, anthesis, kondisi

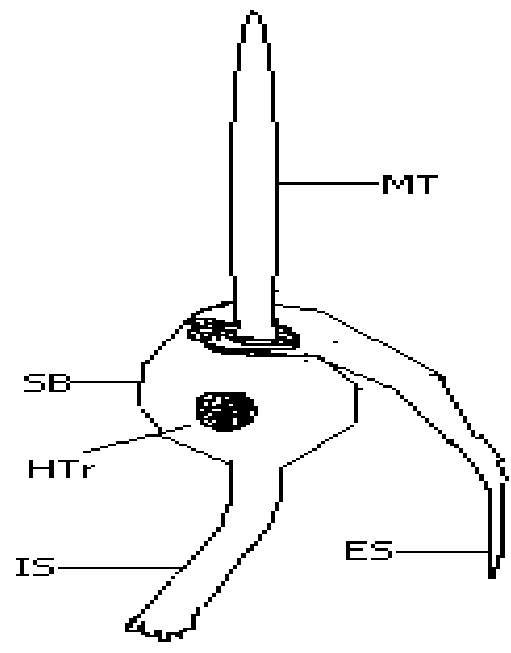

Gambar 1. Sketsa satu tongkol bunga keladi tikus
Tabel 1. Fenologi Perbungaan

\begin{tabular}{lll}
\hline No & \multicolumn{1}{c}{ Item fenologis bunga } & HST \\
\hline 1 & Penanaman & 0 \\
2 & Mulai kuncup & 59 \\
3 & Seludang buka & 61 \\
4 & Mulai layu & 63 \\
5 & Setengah bunga layu & 64 \\
6 & Bunga layu sepurna & 66 \\
7 & Koleksi serbuk terbaik & 61 \\
\hline
\end{tabular}

(HST $=$ Hari Sesudah Tanam)

serbuk sari dan perubahannya. Perlakuan melubangi seludang bunga dengan pisau scalpel, ukuran lubang sekitar $4 \times 5 \mathrm{~mm}$. Pelubangan dilakukan sedemikian rupa sehingga bagian-bagian vital bunga tersebut dapat berhubungan langsung dengan dunia luar. Terbentuknya buah berbiji dipakai sebagai parameter dalam penelitian dianalisa sebagai rasio kesuksesan dan kegagalan pembuahan per rumpun yang diamati. Pada setiap rumpun sebagian tongkol bunga (3-4 tongkol) diberi perlakuan sedangkan sebagian lagi (3-4 tongkol) dibiarkan tanpa perlakuan sebagai kontrol. Total 50 tongkol dari 7 rumpun dipakai dalam penelitian ini (lihat sketsa tongkol bunga: $\mathrm{ES}=$ ujung seludang, $\mathrm{HTr}=$ lubang buatan sebagai perlakuan mutilatif, IS = tangkai tongkol perbungaan, MT = prosesus ekor tikus 'mousetail', SB = kotak seludang 'spathe box' ).

\section{HASIL DAN PEMBAHASAN}

Biologi pembungaan. Dari data fenologis (Tabel 1) terlihat bahwa kuncup bunga pertama akali muncul secara umum pada hari ke 59 setelah penananaman semainya (HST) dan mekar dua hari berikutnya dan kalau tidak terjadi pembuahan atau mungkin saja terjadi kegagalan dalam perkembangan buah/biji, maka pada hari ke 7 sejak mekar (66 HST) bunga akan layu meskipun tidak selalu gugur dari rumpunnya.

Perbungaan $T$. flageliforme adalah bunga majemuk berbentuk tongkol, mempunyai keunikan terutama pada prosesus mouse tailnya yang langsung muncul sejak bunga masih berbentuk kuncup tahap awal. Pertumbuhan memanjang prosesus tersebut terjadi luar biasa cepat. dalam sehari pertambahan panjangnya mencapai $5-7 \mathrm{~cm}$. Struktur propertis tongkol bunga terdiri dari mouse-tail, kelompok bunga jantan, area steril, kelompok bunga betina. Kedudukan masing-masing properties tersebut berurutan dengan posisi segaris arah vertikal sehingga kelompokan bunga-bunga jantan terdapat dalam posisi diatas kelompokan bunga betina. 
Posisi seperti ini sebenarnya sangat potensial untuk penyerbukan sendiri (selfing). Berdasarkan asumsi serbuksari cenderung jatuh ke bawah atau dibawa oleh serangga yang sedang beraktifitas (foraging) dari atas ke bawah pada suatu karangan bunga, disimpulkan bahwa bunga-bunga di bagian bawah dari suatu tongkol (spadix) hermaproditis rata-rata akan menerima lebih banyak serbuksari sehingga lebih sering membentuk buah dibanding dengan yang di bagian atas (Engler 1884, disitir kembali Grayum 1990). Akan tetapi potensi itu tampaknya sedikit dikurangi oleh adanya areal (bunga) steril berbentuk seperti spiral yang terletak antara kelompok bunga jantan dan betina dalam tongkol yang sama. Pada beberapa jenis Theriophorum dan Typhonium terdapat bentuk-bentuk yang berbeda dari bunga-bunga steril pada bagian atas dan bagian bawah di suatu daerah steril pusat; ini diyakini merepresentasikan bunga-bunga jantan dan bungabunga betina yang mandul (Engler 1920, disitir kembali Grayum 1990).

Bunga jantan dan betina tidak mempunyai perhiasan bunga terlihat seperti sebuah anther kecil atau seperti bulatan kecil yang menempel tanpa tangkai pada tongkol. Pada keadaan normal, ketiga propertis tersebut terbungkus oleh kelopak atau seludang berbentuk bungkus membulat (kotak seludang) sedemikian sehingga diperkirakan tidak ada hubungan langsung dengan lingkungan luar, kecuali melalui satusaatunya celah kecil yang terdapat di bawah mousetailnya atau di atas kelompokan bunga jantan tapi diperkirakan tidak bisa dimasuki oleh serangga. Bunga mekar secara sangat sederhana karena hanya mousetailnya saja yang terbuka sedangkan bagian-bagian lainnya masih diiisolasi oleh bungkus seludang tersebut dan tidak ada warna yang menyolok. Marga Typhonium mempunyai dua 'seksi' berdasarkan bentuk bunga (area) sterilnya yaitu Heterostalis (Schott) Engler dan seksi Typhonium (Eutyphonium Engler), tapi tidak selalu berbeda (Engler 1920 disitir kembali Murata 1990). Penelitian terdahulu tentang diversitas morfologi bagian tubuh di atas tanah (shoot) dari marga Typhonium menunjuk kan bahwa T. flagelliforme termasuk jenisjenis kelompok $B 2$ dengan type batang $C$ atau $D$ yang mempunyai plasenta basalis, jumlah bakal biji rendah dan bunga-bunga steril hanya terdapat pada areal antara bunga jantan dan bunga betina (Murata 1990).
Berdasarkan kondisi serbuksari yang kering dan posisi kelompok bunga-bunga jantan yang segaris vertikal dengan kelompok bunga-bunga betina, ada kemungkinan besar penyerbukannya difasilitasi oleh air hujan atau tetesan air yang lain dan mouse-tailnya berperan menuntun aliran air hujan kedalam kotak seludang namun perlu penelitian lebih jauh untuk membuktikan asumsi ini. Diperkirakan tumbuhan ini dapat melakukan penyerbukan mandiri (selfing) karena dapat terbentuk buah atau biji pada tongkol bunga dalam kondisi properti seksual terkurung (bagged) secara alami dalam kotak seludang. Bagian perbungaan pada tongkol (spadix) dibungkusi oleh bagian seludang yang presisten (Backer \& van den Brink 1968). Tetapi secara keseluruhan pembentukan buah sangat jarang tejadi secara alami meskipun jumlah tongkol bunga per rumpun cukup banyak. Hampir semua modifikasi dari seludang pada Araceae berkorelasi erat dengan biologi penyerbukan dan distribusi bunga-bunga jantan dan bunga-bunga betina pada tongkol (spadix) nya (Grayum 1990).

Serbuksari mulai terlepas dari bunga-bunga jantan setelah tengah hari. Pada pukul 13.30-14.00 biasanya serbuksari dapat dikoleksi dengan mudah yaitu dengan cara memukul-mukul daerah bunga jantan sedikit saja dengan jarum preparasi. Pengujian viabilitas serbuksari yang dikoleksi antara pukul 13.30-14.00 menunjukkan viabilitas serbuksari yang tinggi (80\%). Oleh karena itu ada kemungkinan penyerbukan secara alami yang dapat menghasilkan buah terjadi selepas tengah hari dan diharapkan terfasilitasi oleh tetesan hujan yang turun di sore hari.

Induksi pembentukan buah via perlakuan mutilatif. Untuk mengatasi keterbatasan dalam jumlah tongkol bunga yang akan diberikan perlakuan dan untuk menyeragamkan media dan musim untuk semua individu contoh maka hasil pengamatan dikelompokkan menurut rumpun (potting) dan analisa data dilakukan berdasarkan pengelompokan ini. Sebanyak 7 rumpun yang masing-masing ditumbuhkan dalam sebuah pot dipakai dalam penelitian ini. Kesuksesan pembentukan buah sebagai parameter penelitian ini ditentukan hanya sampai pada tingkat ada atau tidaknya buah yang terbentuk pada tongkol yang diteliti tanpa menghitung jumlah buah pertongkol. Jumlah buah pertongkol agak sulit ditentukan karena disamping ukurannya yang kecil 
Tabel 2. Frekuensi kesuksesan (SS) dan kegagalan (FF) pembentukan buah per rumpun dari bunga M. flageliforme yang diperlakukan (TRTD) dan yang tidak diberi perlakuan sebagai kontrol (CTRL). Nilai rata-rata kesuksesan dan standar deviasi adalah berbeda nyata pada uji $\mathrm{F}(\mathrm{F}$ test $=0,0038)$.

\begin{tabular}{ccccc}
\hline Kode Rumpun & $\begin{array}{c}\text { Kesuksesan } \\
\text { Pembentukan Buah } \\
\text { SSTRTD }(\%)\end{array}$ & $\begin{array}{c}\text { Kegagalan } \\
\text { Pembentukan Buah } \\
\text { FFTRTD }(\%)\end{array}$ & $\begin{array}{c}\text { Kesuksesan } \\
\text { Pembentukan Buah } \\
\text { SSCTRL }(\%)\end{array}$ & $\begin{array}{c}\text { Kegagalan } \\
\text { Pembentukan Buah } \\
\text { FFCTRL }(\%)\end{array}$ \\
\hline 1 & 87,5 & 12,5 & 25 & 75 \\
2 & 75 & 25 & 0 & 100 \\
3 & 0 & 100 & 0 & 100 \\
4 & 100 & 0 & 0 & 100 \\
5 & 100 & 0 & 0 & 100 \\
6 & 33,3 & 66,7 & 0 & 100 \\
7 & 50 & 50 & $3,57 \pm 9,45$ & \\
\hline Rata-Rata \pm Std & $63,69 \pm 37,64$ & &
\end{tabular}

A

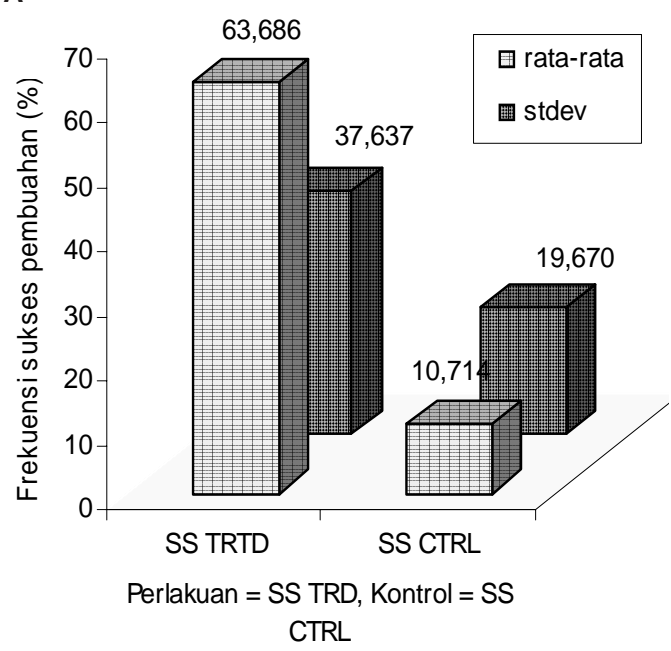

Gambar 2. Frekuensi keberhasilan pembentukan buah (berbiji) pada tongkol yang diberikan perlakuan (SS TRTD) dan kontrol (SS CTRL) (A). Frekuensi kegagalan pembentukan buah (berbiji) pada tongkol yang diberikan perlakuan (FF TRTD) dan kontrol (FF CTRL) (B).

dan jumlahnya bisa sangat banyak, juga sulit dibedakan antara bakal buah dengan buah/biji terutama pada tahap awal terbentuknya buah. Meskipun demikian penelitian lanjutannya mungkin perlu dilakukan untuk mempelajari tentang efisiensi penyerbukan yang dapat dihubungkan dengan jumlah biji yang terbentuk per tongkol.

Dua kelompok data (aray) kesuksesan pembentukan buah yang terkumpul (SSTRD untuk tongkol-tongkol yang diberi perlakuan dan SSCTRL untuk tongkol-tongkol kontrol) diuji dengan $\mathrm{F}$ test. Hasilnya, secara keseluruhan tongkol-tongkol yang mendapat perlakuan mempunyai frekuensi keberhasilan pembentukan buah yang berbeda nyata (Ftest $=0,0038$ ) dan jauh lebih tinggi dari pada kontrol sehingga secara umum kesuksesan pembentukan buah jauh lebih tinggi dari pada kesusksesan pada kontrol, sebaliknya kontrol menunjukkan rasio kegagalan jauh lebih tinggi dari pada tanaman yang diberi perlakuan seperti tercantum dalam Tabel 2, Gambar 2A, dan Gambar 2B. Jadi perlakuan pelubangan seludang bunga dapat memperbesar kemungkinan terjadinya pembentukan buah atau kotak seludang bunga yang utuh sedikit banyak berhubungan dengan rendahnya pembentukan buah pada tanaman ini.

Secara umum keberhasilan pembuahan tergantung terutama pada okupasi serbuksari subur pada kepala putik (penyerbukan) dan kelancaran perkembangan buluh serbuksari dalam pistil sehingga dapat mencapai ovarium (Darjanto \& Satifah 1990). Kegagalan pembentukan buah oleh karena itu berhubungan dengan penghambatan oleh kotak seludang bunga. Meskipun perlu klarifikasi lebih jauh, penghambatan itu kemungkinan besar terjadi pada proses penyerbukan baik dari luar (eksogami) maupun 
dari dalam (otogami). Hambatan terhadap penyerbukan dari luar bisa jadi karena kotak seludang secara fisik menghambat transportasi serbuksari bunga dari individu lain oleh agen penyerbuk. Hambatan terhadap penyerbukan sendiri (otogami) mungkin terjadi karena kotak seludang bunga menutup sedemikian rupa sehingga mengganggu masuk dan keluar air di waktu hujan dan akibatnya serbuksari tidak tepat jatuh ke atas kepala putik bunga-bunga betina. Tapi yang perlu dikaji juga dimasa depan adalah tentang viabilitas dan fsiologi buluh serbuksarinya karena sering terjadi interaksi baik sesama serbuksari maupun antara serbuksari dengan pistil (Pasonen et al, 2001). Dibalik itu ada dua kemungkinan perlakuan mutilatif, dengan membuat lubang kecil pada bungkus seludangnya itu, dapat menginduksi pembentukan buah dan biji. Pertama, secara fisik perlakuan dapat membuka isolasi struktural bagian-bagian tongkol bunga yang penting dalam perkelaminan bunga dan karena itu serangga (lalat dII) terlihat sering berkunjung kebunga, bisa masuk dan berperan sebagai agen penyerbukan. Kedua, perlakuan mutilatif tersebut dapat merangsang terakumulasinya zat-zat penginduksi perkecambahan serbuksari dan kemudian mengoptimalkan pertumbuhan selanjutnya dari buluh serbuksari. Stigma pada bunga yang diberi perlakuan mutilasi dapat mengandung gula, protein dan senyawa-senyawa fenol dua kali lipat pada bunga yang tidak dimutilasi dan diperkirakan kondisi stigma yang sedemikian dapat lebih meningkatkan terjadinya pembuahan (Sreekala \& Sreedevi 2001). Selain itu mungkin juga perubahan kandungan zat-zat seperti itu mempengaruhi secara positif perkembangan pembentukan buah dan biji setelah proses pembuahan terjadi. Vogt et al, (1994), menunjukkan bahwa pelukaan (wounding) daun mahkota bunga dapat membantu perkembangan buah dan meningkatkan pembentukan biji pada marga Petunia. Hal ini dapat dihubungkan dengan akumulasi flavonol terutama adanya senyawa kaemferol pada stigma/pistil sebagai salah satu akibat dari pelukaan tersebut. Dengan beberapa modifikasi yang layak, tekniknya sudah diadopsi untuk bunga yang melakukan penyerbukan sendiri, penyerbukan silang dan bunga yang tidak dimutilasi. Pembentukan buah hanya terjadi pada bunga-bunga yang diberi perlakuan dan bunga yang terpolinasi. Akan tetapi ada perbedaan waktu yang terjadi antara puncak produksi kaemferol dengan perkecambahan serbuk sari (Taylor \&
Jorgensen 1992) dan ini mengindikasikan ketidakmungkinan kaemferol berperan langsung dalam bioreproduksi tumbuhan. Meskipun demikian, suatu yang perlu dibahas adalah mekanisme penghantaran sinyal dari situs pelukaan sampai ke stigma bunga. Senyawa penghantar sinyal belum diketahui kecuali dugaan bahwa etilen merupakan suatu kemungkinan yang menarik untuk dikaji lebih lanjut mengingat senyawa ini dihasilkan oleh stigma segera setelah penyerbukan dan sebagai respon terhadap pelukaan (Hoeckstra \& Weges 1968).

Penelitian lanjutan dengan skala yang lebih besar mungkin diperlukan untuk aplikasinya di lapangan mengingat penelitian pendahuluan ini terhenti sebelum selesai seperti rencana karena tumbuhan koleksi habis terkena serangan ulat musim kemarau.

Percobaan penanaman biji hasil induksi pembentukan buah dengan perlakuan mutilatif menunjukkan bahwa perkecambahan biji cukup sulit terjadi bahkan semula diperkirakan steril. Perkecambahan pertama terjadi setelah hampir 3 bulan dengan frekuensi yang rendah sekali yaitu sekitar $5 \%$. Meskipun demikian tampaknya pengecambahan memerlukan waktu yang cukup lama, sampai makalah ini ditulis perkecambahan masih saja ada yang baru dan sedang berlangsung. Kemungkinan lain adalah pengecambahan biji memerlukan lingkungan yang tertentu. Untuk itu perlu penelitian dan inovasi fisiologis untuk pembudidayaan dan konservasinya di masa depan.

\section{KESIMPULAN}

Perlakuan mutilatif atau melubangi kotak seludang pada bunga keladi tikus Typhonium multiflagela dapat menginduksi peningkatan keberhasilan pembentukan buah berbiji. Oleh karena itu kemungkinan besar ada efek hambat kotak seludang terhadap pembentukan buah. Mekanisme penghambatan memerlukan penelitian lebih lanjut. Meskipun demikian penghambatan oleh kotak seludang dapat bersifat parsial dan ekternal karena pada kontrol meskipun jauh lebih jarang tetapi masih bisa terbentuk buah/ biji secara alami. Penelitian dengan skala yang lebih besar masih perlu dilakukan untuk diterapkan dalam pembudidayaannya kelak. 


\section{UCAPAN TERIMAKASIH}

Terima kasih diucapkan, kepada Puslit Biologi LIPI atas perizinan perjalanan eksplorasi dan pendanaan penelitian ini melalui Proyek Pengkajian \& Pemanfaatan Sumberdaya Hayati, kepada Pemerintah Provinsi Jawa Tengah, Pemerintah Kotamadya Pekalongan atas perizinan eksplorasi dan informasi tentang keladi tikus dan habitatnya terutama dalam kawasan Kotamadya Pekalongan.

\section{DAFTAR PUSTAKA}

Backer, C.A. \& van den Brink, B. 1968. Flora of Java Vol III, Spermatophyte Only. The Netherland: n.v Nordhoff, Groningen.

Darjanto \& S. Satifah. 1990. Pengetahuan Dasar Biologi Bunga dan Teknik Penyerbukan Buatan. Ed IV. Jakarta: PT Gramedia.
Grayum, M. H. 1990. Evolution and phylogeny of the Araceae. Annals of the Missouri Botanical Garden 77: 628-697.

Keng, H. 1978. Orders and Families of Malayan Seed Plants. Singapore: Singapore University Press.

Hoeckstra, F.A. \& Weges, R. 1968. Lack of control by early pistillate ethylene of the accelerated wilting of petunia hibrida flowers. Plant Physiology 80: 403-408.

Murata, J. 1990. Diversity of shoot morphology in Typhonium (Araceae). American Journal of Botany 77: 1475-1481.

Pasonen, H-L., Pulikkinen, P. \& Kapila, M. 2001. Do Pollen Donors with Fastest- growing Pollen Tubes Sire The Best Offspring in Anemophilous Tree,Betula pendula (Betulaceae). American Journal of Botany 88: 854 - 860.

Sreekala, A.K. \& Sreedevi, P. 2001. Induceed seed set in Alamanda cathartica L. Phytomorphology 51: 173-180.

Taylor, L. P. \& Jorgensen, R. 1992. Conditional Male Fertility in Chalcone Synthese-Defficient Petunia. Journal of Heredity 83: $11-17$.

Teo, C.K.H \& Teo, C.B.I. 1999. Cancer-Yet They Live. Cancer Care 5 Lorong 13. Penang, Malaysia: Minden Heights.

Vogt, T., Pollack, P., Tarlyn, N. \& Taylor, P. 1994. Pollination-or wound-induceed kaempferol accumulation in Petunia stigmas enhances seed production. The Plant Cell 6: 11-23. 